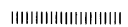

Note

||||||||||||||||||||||

\section{Metabolism of Fenitrothion in Several Brackish and Marine Zooplankton Species}

\author{
Shosaku KaSHIwADA, ${ }^{1}$ Kazuo MochIDA, \\ Yoshihisa OzoE and Toshiie NAKAMURA \\ Department of Life Science and Biotechnology, Faculty of Life \\ and Environmental Science, Shimane University, \\ 1060 Nishikawatsu, Matsue, Shimane 690-8504, Japan
}

(Received December 8, 1997 ; Accepted March 16, 1998)

\section{INTRODUCTION}

There are many reports on toxicity tests of pesticides carried out to aquatic organisms and some reviews ${ }^{1,2)}$ have been published. The aquatic organisms used in the toxicity test were the representative of all organisms, but not always dominant in an aquatic environment. Although Daphnia has usually been used as a test zooplankton, it is a representative zooplankton in the freshwater aquatic environment. Therefore, it is not preferable to presume influences and fate of pesticides on brackish or marine zooplankton solely referring to those data. In previous studies, ${ }^{3,4)}$ it has been clarified that Sinocalanus tenellus and Oithona davisae, dominant zooplankton species in brackish lakes, Lake Shinjiko and Lake Nakanoumi, respectively, and marine zooplankton species, Brachionus plicatilis and Artemia salina, have tolerance and degrading ability to organophosphorus insecticides. It was considered that these brackish zooplankton might play a role as the decomposer of insecticides in these lakes. These reports were valuable themselves as investigations estimating the influence of zooplankton on the fate of insecticides in the two brackish lakes using the dominant zooplankton species. However, metabolites of the insecticides formed in these zooplankton species were not examined. Although a few reports ${ }^{5,6}$ on the metabolism of insecticides in Daphnia were available, investigations on metabolism of insecticides using some vital dominant zooplankton species in the aquatic environment needed to be pursued. In this study, major metabolites of fenitrothion, a representative organophosphorus insecticide, formed in $S$. tenellus, $O$. davisae, $B$. plicatilis and $A$. salin $a$ are identified by using ${ }^{14} \mathrm{C}$-labeled fenitrothion, and the toxicity of the metabolites to the zooplankton species is estimated by $\mathrm{LC}_{50}$ values.

\footnotetext{
1 Present address: 21-6-103 Higashi, Fujieda, Shizuoka 426-
} 0038, Japan. E-mail address: kasiwada@quartz.ocn.ne.jp

\section{MATERIALS AND METHODS}

\section{Zooplankton}

S. tenellus, $O$. davisae, B. plicatilis and $A$. salina were used in this work (Table 1). Copepoda S. tenellus and O. davisae are dominant zooplankton species in brackish lakes, Lake Shinjiko and Lake Nakanoumi, respectively, and rotatoria $B$. plicatilis is a member of zooplankton community in Lake Nakanoumi. B. plicatilis and anostraca $A$. salina are generally used as foods for young fish in a fish-raising industry, and A. salina is rarely used as a test zooplankton species in toxicity test for chemicals. Their tolerance to fenitrothion were also shown in Table 1 as $\mathrm{LC}_{50}$ values. The methods for collection, rearing and isolation of these zooplankton species were described in a previous paper. ${ }^{3)}$

\section{Chemicals}

Fenitrothion ( $O, O$-dimethyl 4-nitro- $m$-tolylphosphorothioate, technical grade 96.3\%) and radioactive fenitrothion $(1.45 \mathrm{GBq} / \mathrm{mmol}$, the radiochemical purity over $99 \%){ }^{14} \mathrm{C}$ labeled at $m$-methyl group of the phenyl moiety were donated by Sumitomo Chemical Co., Ltd. To identify metabolites of fenitrothion, fenitrooxon ${ }^{7}$ (O,O-dimethyl $O$-(3-methyl-4nitrophenyl) phosphorate) and desmethylfenitrooxon $\left.{ }^{8}\right)(O$ methyl $O$-hydrogen $O$-(3-methyl-4-nitrophenyl) phosphorate) were synthesized authentically in our laboratory. These authentic compounds were ascertained by TLC, CHN, GC-MS and NMR analyses. 3-Methyl-4-nitrophenol was purchased from Nacalai Tesque Inc.

\section{Metabolism of Fenitrothion by Zooplankton}

The experiment was carried out by using ${ }^{14} \mathrm{C}$-labeled fenitrothion. Artificial brackish water or seawater (Haipetto Co. Ltd., pH 7.0, respectively) were used in this work. The two kinds of artificial brackish water were made by dilution of artificial seawater to 10 and $50 \%$, and used as the brackish water corresponding to the water of lakes Shinjiko and Nakanoumi, respectively. The brackish water and seawater were sterilized by passing through a $0.2-\mu \mathrm{m}$ membrane filter (Toyo Roshi Kaisha Ltd.). To $20 \mathrm{ml}$ of the sterilized artificial brackish water or seawater containing zooplankton (Table 1), a $300 \mu$ l of acetone solution containing ${ }^{14} \mathrm{C}$-labeled fenitrothion $(110 \mathrm{~Bq} / \mu \mathrm{l})$ was added. The concentration of fenitrothion $(0.32 \mathrm{ppm})$ was confirmed to have no effect on zooplankton. Zooplankton was incubated with reciprocal shaking at $20^{\circ} \mathrm{C}$ for $24 \mathrm{hr}$. As a control, sterilized artificial brackish water or seawater in the absence of zooplankton was incubated under the same conditions. Fifty-microliter portions of incubation solution were pipetted out at appropriate time intervals and were conducted for TLC analysis with the authentic compounds, such as fenitrothion, fenitrooxon, desmethylfenitrooxon and 3-methyl-4-nitrophenol, to identify 
metabolic products. The TLC analyses were carried out with silica gel $60 \mathrm{~F}-254$ precoated chromatoplates $(0.25 \mathrm{~mm}$ gel thickness, E. Merck, Germany). The solvent systems are referred to as an investigation of J. Miyamoto et. al. ${ }^{\text {) }}$ The TLC plates were analyzed by a TLC scanner (AMBIS 4000, AMBIS Inc.).

After the 24-hr incubation, zooplankton were collected by filtering the incubated solution through a glass microfibre filter (GF/C, Whatman International Ltd.). The collected zooplankton was rinsed with a $10 \mathrm{ml}$ of sterilized artificial seawater. The zooplankton on the glass filter was ground with $\mathrm{Al}_{2} \mathrm{O}_{3}$ and extracted five times with $3-\mathrm{ml}$ portions of $\mathrm{MeOH}$. These $\mathrm{MeOH}$ extracts were combined, evaporated to dryness, and redissolved in $500 \mu 1$ of $\mathrm{MeOH}$. Then, a $50 \mu 1$ portion of the solution was subjected to TLC analysis.

The TLC-silica gel of each radioactive region was scraped off and $5 \mathrm{ml}$ of toluene scintillation cocktail was added to this. The radioactivity was determined by a liquid scintillation counter (LS 6000 SE, Beckman Instruments, Inc.).

Table 1 Number of zooplankton used for the metabolism of ${ }^{14} \mathrm{C}$-fenitrothion and the reported $\mathrm{LC}_{50}$ values of fenitrothion.

\begin{tabular}{lcc}
\hline Zooplankton & Number & $\mathrm{LC}_{50}(\mathrm{ppm})^{4)}$ \\
\hline S. tenellus & 290 & $2.8(2.5-3.1)^{\mathrm{a})}$ \\
O. davisae & 4500 & $1.6(1.4-1.7)$ \\
B. plicatilis & 7000 & $5.4(4.9-6.0)$ \\
A. salina & 150 & $>12$ \\
\hline
\end{tabular}

a) Ninety-five percent confidence limits are given in parentheses.

\section{Toxicity of Fenitrothion-metabolites}

Toxicity of the metabolites to zooplankton was evaluated by $50 \%$ lethal concentration $\left(\mathrm{LC}_{50}\right)$. The detailed description of the method was given in a previous paper. ${ }^{3)}$

\section{RESULTS AND DISCUSSION}

As major degrading products of ${ }^{14} \mathrm{C}$-fenitrothion, 3-methyl4-nitrophenol, fenitrooxon and desmethylfenitrooxon were detected from the incubated solution in the presence of zooplankton (Table 2). In the control brackish water, corresponding to the water of Lake Nakanoumi, and in the control seawater both containing no zooplankton, no metabolite of ${ }^{14} \mathrm{C}$-fenitrothion was detected (Table 3). 3-Methyl-4nitrophenol was detected only from the solution in the absence of $S$. tenellus, corresponding to the water of Lake Shinjiko. The detection of 3-methyl-4-nitrophenol in the presence of $S$. tenellus was after $6 \mathrm{hr}$, while that in its absence was after $12 \mathrm{hr}$. Therefore, it was suggested that 3-methyl-4nitrophenol, fenitrooxon and desmethylfenitrooxon were the metabolites of fenitrothion formed in the four zooplankton species. In whole body of $O$. davisae and $A$. salina, 3methyl-4-nitrophenol, fenitrooxon and desmethylfenitrooxon were also detected (Table 2). The proportions of fenitrooxon in bodies of these two zooplankton species were the lowest of all detected metabolites. Fenitrooxon was not detected in whole body of $S$. tenellus and $B$. plicatilis. Desmethylfenitrooxon in zooplankton body showed a higher proportion than that of fenitrooxon. This tendency was also shown in the incubated solution of four zooplankton species. It was considered that most fenitrooxon was metabolized to desmethylfenitrooxon in zooplankton body, although a part

Table 2 Proportions of ${ }^{14} \mathrm{C}$-labeled fenitrothion and its metabolites detected from water in the presence of zooplankton and from zooplankton body after a 24-hr incubation.

\begin{tabular}{|c|c|c|c|c|c|c|c|c|}
\hline \multirow{3}{*}{ Compound } & \multicolumn{8}{|c|}{ Proportion (\%) } \\
\hline & \multicolumn{2}{|c|}{ S. tenellus } & \multicolumn{2}{|c|}{ O. davisae } & \multicolumn{2}{|c|}{ B. plicatilis } & \multicolumn{2}{|c|}{ A. salina } \\
\hline & Water & Body & Water & Body & Water & Body & Water & Body \\
\hline Fenitrothion & 64.5 & 90.7 & 70.6 & 40.6 & 80.08 & 85.95 & 88.3 & 60.5 \\
\hline 3-Methyl-4-nitrophenol & 9.6 & 9.3 & 6.3 & 27.9 & 10.28 & N.D. & 3.1 & 3.8 \\
\hline Fenitrooxon & 3.7 & N.D. ${ }^{\text {a) }}$ & 7.1 & 0.1 & 2.07 & N.D. & 1.5 & 1.9 \\
\hline Desmethylfenitrooxon & 10.2 & N.D. & 10.7 & 6.7 & 5.26 & 2.38 & 2.4 & 4.5 \\
\hline Unknown & 11.9 & N.D. & 5.5 & 24.8 & 2.3 & $<11.7$ & 4.7 & 29.3 \\
\hline
\end{tabular}

a) Not detected.

Table 3 Proportions of ${ }^{14} \mathrm{C}$-labeled fenitrothion and its metabolites detected from artificial brackishwater corresponding to water of Lake Shinjiko and Lake Nakanoumi, and artificial seawater after a 24-hr incubation.

\begin{tabular}{lccc}
\hline \multirow{2}{*}{ Compound } & \multicolumn{2}{c}{ Brackishwater } & \multirow{2}{*}{ Seawater } \\
\cline { 2 - 3 } & Lake Shinjiko & Lake Nakanoumi & \\
\hline Fenitrothion & 88.1 & 100.0 & 100.0 \\
3-Methyl-4-nitrophenol & 11.9 & 0.0 & 0.0 \\
Fenitrooxon & 0.0 & 0.0 & 0.0 \\
Desmethylfenitrooxon & 0.0 & 0.0 & 0.0 \\
Unknown & 0.0 & 0.0 & 0.0 \\
\hline
\end{tabular}


Table 4 Twenty-four hour $\mathrm{LC}_{50}$ values of fenitrothion and its metabolites for brackish and marine zooplankton.

\begin{tabular}{lccc}
\hline \multirow{2}{*}{ Insecticide } & \multicolumn{3}{c}{$\mathrm{LC}_{50}(\mathrm{ppm})$} \\
\cline { 2 - 4 } & S. tenellus & O. davisae & B. plicatilis \\
\hline Fenitrothion & $2.8(2.5-3.1)^{\mathrm{a})}$ & $1.6(1.4-1.7)$ & $5.4(4.9-6.0)$ \\
\hline 3-Methyl-4-nitrophenol & $0.94(0.65-1.4)$ & $>3.0$ & $6.35(5.0-8.0)$ \\
Fenitrooxon & $0.12(0.11-0.14)$ & $0.26(0.24-0.28)$ & $>40.0$ \\
Desmethylfenitrooxon & $>40.0$ & $>40.0$ & $>40.0$ \\
\hline
\end{tabular}

a) Ninety-five percent confidence limits are given in parentheses.

of fenitrooxon was eliminated immediately from zooplankton body. Takimoto ${ }^{5)}$ studied metabolism of fenitrothion by Daphnia and reported that major decomposition product detected in the water or the zooplankton body was 3-methyl4-nitrophenol or desmethylfenitrooxon, respectively, and others were fenitrooxon, desmethylfenitrothion and 3-methyl4-nitrophenyl sulfate. In our study, desmethylfenitrothion and 3-methyl-4-nitrophenyl sulfate were not detected. Gaelli et $a l{ }^{6)}$ also reported $\mathrm{PO}$-oxidized analogs of disulfoton and thiometon, organophosphorus insecticides, were detected as the decomposition compounds formed in Daphnia.

These results suggested that the brackish, marine and freshwater zooplankton certainly metabolized fenitrothion to 3methyl-4-nitrophenol, fenitrooxon and desmethylfenitrooxon, etc. Organophosphorus insecticides might be metabolized by esterase, glutathion $S$-transferase (GST) and mixed function oxygenase (mfo) in zooplankton body. Bowman et $a l^{10)}$ and LeBlanc and Cochrane ${ }^{11)}$ reported on GST as the metabolic enzyme of zooplankton for xenobiotics. However, there is no report of esterase and oxygenase in zooplankton. Our results would be evidences that zooplankton metabolized xenobiotics not only by GST but also by esterase and oxygenase.

To estimate toxicity of the metabolites, their $\mathrm{LC}_{50}$ values for the zooplankton species were measured (Table 4). Although 3-methyl-4-nitrophenol showed a higher toxicity than fenitrothion to $S$. tenellus, it showed a lower toxicity to $O$. davisae and $B$. plicatilis. The $\mathrm{LC}_{50}$ values of desmethylfenitrooxon for the zooplankton species were $>40 \mathrm{ppm}$ and this metabolite showed no influence on tested zooplankton species. Toxicity of fenitrooxon, known to be higher acetylcholine inhibitor than fenitrothion to insects, to $S$. tenellus and $O$. davisae was the highest among three metabolites. However, the toxicities to these species were only 23 and 6.2 times higher than those of fenitrothion, respectively, and no toxicity was shown to $B$. plicatilis even at $40 \mathrm{ppm}$. A. salina showed the highest tolerance in spite of the highest ratio of fenitrooxon in body of tested zooplankton species (Tables 1 and 2). Gaelli et al. ${ }^{6}$ ) reported on the toxicities of POoxidized analogs of disulfoton and thiometon for Daphnia in acute immobilization test, and showed that the toxicities of the PO-oxidized analogs were only 5.5 and 29 times higher than those of disulfoton and thiometon, respectively. Therefore, toxicities of PO-oxidized analogs of fenitrothion, disul- foton and thiometon for zooplankton would not be extremely high compared to these parent compounds.

In this study, some metabolites of fenitrothion produced by brackish and marine zooplankton species were ascertained. Fenitrothion applied to paddy field is spread to lakes and sea through rivers. Maru ${ }^{12)}$ reported the concentration of fenitrothion in drain water of paddy fields was at $0.1-1 \mathrm{ppb}$ in June. The concentration of fenitrothion in water of the lakes Shinjiko and Nakanoumi have not been measured. However, the concentrations are estimated to be lower than that in the drain water of paddy fields. Then, S. tenellus, $O$. davisae and B. plicatilis are supposed to decompose fenitrothion in these lakes with no apparent influence on their lives by fenitrothion and its metabolites.

On the other hand, it is still unknown to what extent a long-term exposure of pesticides will influence on the pesticide-tolerance and the pesticide-degrading activity of zooplankton in the aquatic environment. These examinations should be pursued for exact evaluation of impacts of a pesticide on aquatic microorganisms.

\section{REFERENCES}

1) T. Tanaka, ed.: "Suiseiseibutu to Nouyaku," Scientist Co., Tokyo (1978) (in Japanese)

2) Y. Nishiuchi, ed.: "Zoku - Suiseiseibutu to Nouyaku," Scientist Co., Tokyo (1983) (in Japanese)

3) S. Kashiwada, K. Mochida, Y. Ozoe \& T. Nakamura: $J$. Pesticide Sci. 20, 161 (1995)

4) S. Kashiwada, K. Mochida, Y. Ozoe \& T. Nakamura: $J$. Pesticide Sci. 20, 503 (1995)

5) Y. Takimoto, Thesis accepted by Kyoto University for the Degree of Doctor: "Studies on the fate in the aquatic environment and effects on the aquatic organisms of an organophosphorus insecticide - fenitrothion" (1984)

6) R. Gaelli, H. W. Rich \& R. Scholtz: Aquatic Toxicol. 30, 259 (1994)

7) J. Miyamoto, N. Mikami, K. Mihara, Y. Takimoto, H. Kohda \& M. Suzuki: J. Pesticide Sci. 3, 35 (1978)

8) J. Miyamoto: Agric. Biol. Chem. 28, 411 (1964)

9) J. Miyamoto, K. Mihara \& S. Hosokawa: J. Pesticide Sci. 1, 9 (1976)

10) B. P. Bowman, T. W. Snell \& B. J. Cochrane: Comp. Biochem. Physiol. 95B, 619 (1990)

11) G. A. LeBlanc \& B. J. Cochrane: Comp. Biochem. Physiol. 82C, 37 (1985)

12) S. Maru: J. Pesticide Sci. 18, S135 (1993) 
要

約

汽水産および海産の動物プランクトンにおけるフェニ トロチオンの代謝

柏田祥策，持田和男，尾添嘉久，中村利家 汽水域および海域における，有機りン殺虫剤フェニトロチオ ンの環境水中運命に及ばす動物プランクトンの影響を明らかに することを目的に， ${ }^{14} \mathrm{C}$ で標識したフェニトロチオンを用いて 汽水産および海産の動物プランクトンに起因するフェニトロチ オン代謝生産物の同定およびそれらの動物プランクトンに対す る毒性について検討した。汽水湖である宾道湖および中海の優 占種それぞれ Sinocalanus tenellus および Oithona davisae，海
産動物プランクトン Brachionus plicatilis および Artemia salina のフェニトロチオン代謝生産物として, 3-methyl-4-nitrophenol, fenitrooxon および desmethylfenitrooxon を動物プランクトン 体内または飼育溶液中から検出・同定した。供試動物プランク トンに対する desmethylfenitrooxon $の \mathrm{LC}_{50}$ 值はいずれも>40 ppmであり，ほとんど毒性を示さなかった。一方，3-methyl-4nitrophenol のS. tenellusに対する $\mathrm{LC}_{50}$ 值は $0.94 \mathrm{ppm}$, fenitrooxon の S. tenellus および O. davisae に対する $\mathrm{LC}_{50}$ 值は それぞれ $0.12 \mathrm{ppm}$ および $0.26 \mathrm{ppm}$ であり，フェニトロチオン のそれ（それぞれ $2.8 \mathrm{ppm}$ および $1.6 \mathrm{ppm})$ より高い毒性を示し た。 